\title{
Relaxation parameters of water molecules coordinated with Gd(III) complexes and hybrid materials based on $\delta$-FeOOH (100) nanoparticles: A theoretical study of hyperfine inter-actions for CAs in MRI
}

\author{
Mateus Aquino Gonçalves ${ }^{1+}$ (i) , Teodorico Castro Ramalho ${ }^{1}$ (i) \\ 1. Department of Chemistry, Federal University of Lavras, Lavras, Minas Gerais, Brazil
}

${ }^{+}$Corresponding author: Mateus Aquino Gonçalves, Phone: +55 35 992310551, Email address: mateusufla@gmail.com

$\begin{array}{ll}\text { ARTICLE INFO } & \text { Keywords: } \\ & \text { 1. gadolinium } \\ \text { Article history: } & \text { 2. dynamics } \\ \text { Received: November 29, } 2019 & \text { 3. interactions hyperfine } \\ \text { Accepted: March 23, 2020 } & \text { 4. contrast agents } \\ \text { Published: } \text { October } 01,2020 & \text { 5. MRI }\end{array}$

ABSTRACT: Cancer is a serious disease that afflicts and worries much of the population, which significantly affects all ages and socio-economic groups and one reason is the great difficulty of the initial diagnostic phase. Thus, magnetic resonance imaging (MRI) is an effective technique for detecting cancer (especially breast cancer), however, for a better visualization of the tissues it is necessary to use the Contrast Agents (CAs), which are paramagnetic compounds capable of increasing the longitudinal and transverse relaxation times $\left(\mathrm{T}_{1}\right.$ and $\left.\mathrm{T}_{2}\right)$ of water molecules. The CAs are important to increase the rate of relaxation of water protons, the most commonly used CAs are $\mathrm{Gd}^{3+}$ complexes. Thus, in this work we propose two new hybridizing contrast agent, $\delta$ - $\mathrm{FeOOH}(100)$. [Gd(DTPA) $\left.\left(\mathrm{H}_{2} \mathrm{O}\right)\right]^{2-}$ and $\delta$-FeOOH (100). $\left[\mathrm{Gd}(\mathrm{DTPA}-\mathrm{BMA})\left(\mathrm{H}_{2} \mathrm{O}\right)\right]$, both compounds are capable of increasing both relaxation times $\mathrm{T}_{1}$ and $\mathrm{T}_{2}$. Theoretical results show that the hybrid compound considerably increases the hyperfine coupling constants ${ }^{1} \mathrm{H}$ and ${ }^{17} \mathrm{O}$ of water molecules. In this way, our results show that both hybrid compounds can be used as new contrast agents, thus replacing $\mathrm{Gd}^{3+}$ complexes.

\section{Introduction}

The Magnetic Resonance Imaging (MRI) is considered to be an effective technique for diagnosing lesions and cancer. Currently, this technique is widely used in radiology to obtain detailed tissue images ${ }^{1,2}$. Currently, there are many techniques used in the diagnosis of cancer. Among the most used diagnostic techniques for cancer, we can highlight Tomography, Ultrasonic Endoscopy, and Magnetic Resonance Imaging (RMI). RMI is one of the most successful techniques, it is a noninvasive technique based on the magnetic properties of ${ }^{1} \mathrm{H}$ and ${ }^{17} \mathrm{O}$ atoms, which are the most abundant elements in the human body. However, only with the natural relaxation $\left(\mathrm{T}_{1}\right.$ and $\left.\mathrm{T}_{2}\right)$ of these atoms it is not possible to obtain clear images of the tissues, so the Contrast Agents (CAs) are used ${ }^{3}$. CAs are paramagnetic compounds and their use is of utmost importance for a better visualization of the images in the MRI exams. Currently, the most commonly used CAs are $\mathrm{Gd}^{3+}$ complexes with different ligands, such as DOTA, DTPA, EDTA, etc.

The most commonly used CAs are $\mathrm{Gd}^{3+}$ complexes, gadolinium is an internal transition metal belonging to the lanthanide family. Since the initial reports Gd has become the most used metal center for the production of CAs. The seven unpaired 
electrons of $\mathrm{Gd}$ combined with a relatively long relaxation time, makes this lanthanide an effective CAs. Gd has been used as CA since the late 1980s, these CAs alter both $T_{1}$ and $T_{2}$ relaxation times, however studies show that they are more effective in $\mathrm{T}_{1}{ }^{3-5}$. The $\mathrm{Gd}^{3+}$ complexes with poly (aminocarboxylate) ligands are the contrast agents most commonly used commercially, these compounds have nitrogen and oxygen atoms that are able to coordinate with the $\mathrm{Gd}^{3+}$ ion. It is worth stressing that $\mathrm{Gd}$ complexes increase both relaxation rates $\left(r_{1}=1 / T_{1}\right.$ and $\left.r_{2}=1 / T_{2}\right)$, however, a higher longitudinal relaxation rate is observed ${ }^{6,7}$. In contrast, iron oxides have properties that significantly shorten the $\mathrm{T}^{2}$ and $\mathrm{T}^{2^{*}}$ values of tissue water molecules, this characteristic is due to the difference in susceptibility between the iron oxide nucleus and the surroundings water ${ }^{8,9}$. Thus, the two compounds together can have very important properties, especially in the reduction of both relaxation times and these materials are known as hybrid compounds and have been widely studied ${ }^{10}$. Studies show that such hybrid compounds applied in MRI have been shown to be about 8 times larger in imaging effects than Magnevist (widely used CAs) ${ }^{11}$. With that in mind, the purpose of this paper is to investigate the water molecules coordinated with the complexes $\quad\left(\left[\mathrm{Gd} \quad(\text { DOTA })\left(\mathrm{H}_{2} \mathrm{O}\right)\right]^{-}\right.$, $\left[\mathrm{Gd}(\mathrm{DTPA})\left(\mathrm{H}_{2} \mathrm{O}\right)\right]^{2-}$, [ $\left.\left.\mathrm{Gd}(\mathrm{DTPA}-\mathrm{BMA})\left(\mathrm{H}_{2} \mathrm{O}\right)\right]\right)$ and the hybrids $\delta$ - $\mathrm{FeOOH}(100) \cdot\left[\mathrm{Gd}(\mathrm{DTPA})\left(\mathrm{H}_{2} \mathrm{O}\right)\right]^{2-}$ and $\delta$-FeOOH(100). $\left.\left[\mathrm{Gd}(\mathrm{DTPA}-\mathrm{BMA})\left(\mathrm{H}_{2} \mathrm{O}\right)\right]\right)$, where DOTA $=1,4,7,10$-Tetraazacyclododecane-1,4,7,10tetraacetic acid; $\quad \mathrm{DTPA}=\quad 2-[\mathrm{Bis}[2-$ [bis(carboxymethyl)amino]ethyl]amino]acetic acid and $\mathrm{BMA}=$ bis-methylamide, in order to assess the hyperfine interactions of the ${ }^{1} \mathrm{H}$ and ${ }^{17} \mathrm{O}$, studying its applicability as potential contrast agents for tracking of cancer cells. Fig. 1 show the hybrid compounds used in this work.
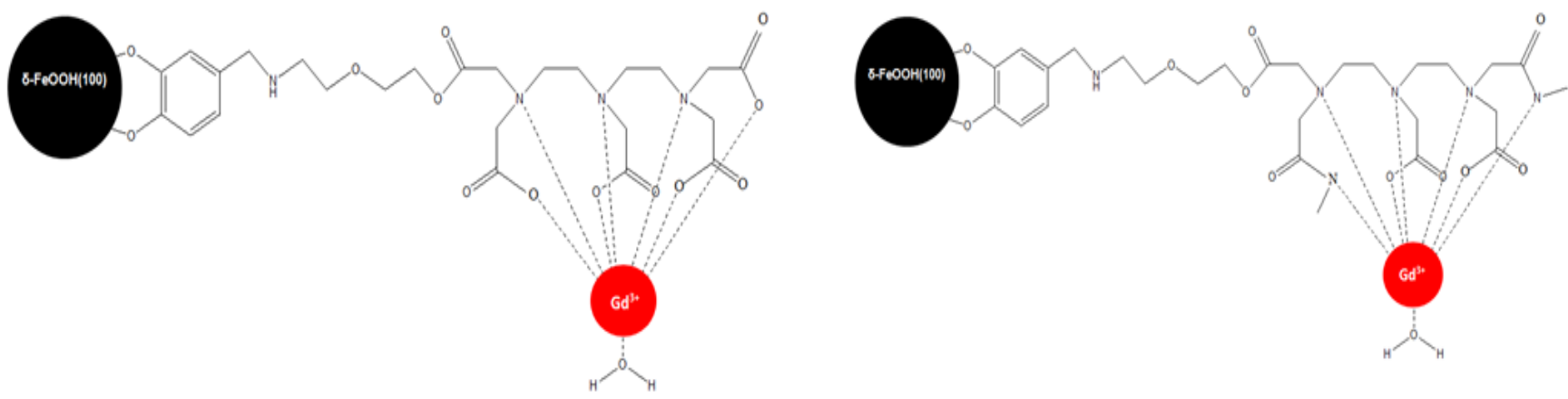

Figure 1. Structure of the hybrid a) $\delta$-FeOOH (100). [Gd(DTPA) $\left.\left(\mathrm{H}_{2} \mathrm{O}\right)\right]^{2-}$ and b) $\delta$-FeOOH (100).[Gd(DTPA$\left.\mathrm{BMA})\left(\mathrm{H}_{2} \mathrm{O}\right)\right]$.

\section{Computational methods}

\subsection{Optimization of structures and Molecular Dynamics Simulations calculations}

Initially optimize the complexes $\left(\left[\mathrm{Gd}(\mathrm{DOTA})\left(\mathrm{H}_{2} \mathrm{O}\right)\right]^{-}, \quad\left[\mathrm{Gd}(\mathrm{DTPA})\left(\mathrm{H}_{2} \mathrm{O}\right)\right]^{2-}\right.$ and [Gd(DTPA-BMA) $\left.\left.\left(\mathrm{H}_{2} \mathrm{O}\right)\right]\right)^{12,13}$ and the hybrids $\delta$ $\mathrm{FeOOH}(100) \cdot\left[\mathrm{Gd}(\mathrm{DTPA})\left(\mathrm{H}_{2} \mathrm{O}\right)\right]^{2-}$ and $\delta$ $\left.\mathrm{FeOOH}(100) \cdot\left[\mathrm{Gd}(\mathrm{DTPA}-\mathrm{BMA})\left(\mathrm{H}_{2} \mathrm{O}\right)\right]\right)$, in the gaussian 09 program $^{14}$, using the semi-empirical Parameterization Method 6 (PM6) ${ }^{15,16}$.

After optimization, we made the molecular dynamics simulations (MD) for the complexes of Gd(III) using the program developed by van Duin and col. (REAX-FF) ${ }^{17}$, which is part of ADFBAND program package. For the simulations was used the force field $\mathrm{NiCH}$. For the MD simulation the box size was fixed at $8000 \AA^{3}$ and was held at a temperature $310.65 \mathrm{~K}$ (physiologic temperature) throughout the simulation. Studies have shown that this temperature is adequate to simulate this type of model. For these simulations a 500 ps thermalization face (for system stabilization) and an additional $2.0 \mathrm{~ns}$ period are required, the box was built by the density of liquid water $(\rho=0.996 \mathrm{~g}$ $\left.\mathrm{cm}^{-3}\right)^{18}$.

\subsection{Statistical inefficiency, surface, and hyperfine coupling constant (HFCC) Calculations}

After the MD simulation it is necessary to try to reduce the number of conformations for the later quantum calculations (decrease the computational cost). For this, we selected the uncorrelated configurations of the Gd(III) complexes, Scilab 
$2.7^{19}$ program was used. The method was developed and applied for the first time by the Canuto's group ${ }^{20}$. This method uses the statistical interval obtained from the energy autocorrelation, the interval between uncorrelated configurations, or the correlation step $\mathrm{s}$, is calculated by integration from zero to infinity of $\mathrm{C}(\mathrm{n})$, Eq. 1. The interval between uncorrelated configurations, or the correlation step $\tau$ (the molecular rotational correlation time in Eq.2) is calculated by integration from zero to infinity of $\mathrm{C}(\mathrm{n})$. The theory shows that separate the settings by $2 \tau$, or larger intervals, are considered uncorrelated.

$$
C(n)=\sum_{i=1}^{N} C_{i} e^{-n / \tau_{i}}
$$

$\tau=\int_{0}^{\infty} C(t) d t$

With uncorrelated structures we did the constant calculations of hyperfine coupling $\left(\mathrm{A}_{\text {iso }}\right)$ for the complexes with water molecules.

The hyperfine coupling constant $\left(\mathrm{A}_{\text {iso }}\right)$ calculations were carried out in the program Gaussian 09, with uncorrelated structures from MD simulation of $\mathrm{Gd}^{3+}$ complexes and with the lowest energy structure of the hybrid. For the $\mathrm{Gd}^{3+}$ complexes, the simulation was performed using the functional PBE1PBE ${ }^{21}$ and basis set EPR-III for the $\mathrm{H}$ and $\mathrm{O}$ atoms, 6-31G for the $\mathrm{C}$ and $\mathrm{N}$ atoms, MWB53 for the Gd atom. For the hybrid compounds was also used the above-mentioned base function and we added the lanl2dz for the Fe atom.

\section{Results}

\subsection{Method validation}

The geometry of the complex was fully optimized using the method PM6, the geometry according mounted as shown in Fig. 2 and the bond distances from the metal coordination environment are listed in Tab. $1^{7}$

From the results of Tab. 1, it is possible to observe that our calculations were able to reproduce reasonably well the distances between the $\mathrm{Gd}^{\mathrm{III}}$ and the ligand, observed with the experimental results performed by $\mathrm{x}$-ray.

We observed for the complex that $\left[\mathrm{Gd}(\mathrm{DOTA})\left(\mathrm{H}_{2} \mathrm{O}\right)\right]^{-}$, the inner sphere water molecule has a bond distance around $2.45 \AA$, what satisfies our theoretical value $2.56 \AA$. For the complexes $\left[\mathrm{Gd}(\mathrm{DPTA})\left(\mathrm{H}_{2} \mathrm{O}\right)\right]^{-}$and $[\mathrm{Gd}(\mathrm{DTPA}-$ BMA $)\left(\mathrm{H}_{2} \mathrm{O}\right)$ ] water molecules in the inner sphere have a connection distance between $2.49 \AA$, and $2.44 \AA$, which satisfies the theoretical values 2.52 $\AA$ and $2.46 \AA$, respectively. This can be attributed, at least in part, to the fact that the implicit solvation model (which uses the dielectric constant of the medium) cannot explain some specific interactions between the complex and the solvent, for example, the hydrogen bonds. Indeed, it has been shown that continuous dielectric solvent models are often inadequate to investigate solutes that concentrate on the charge density with strong local solutesolvent interactions ${ }^{7}$. Thus, to try to overcome this deficiency, we performed calculations of geometry optimization using only one coordinated water molecule with Gd. Table 1 shows the distances of the complex bonds compared with the experimental values.

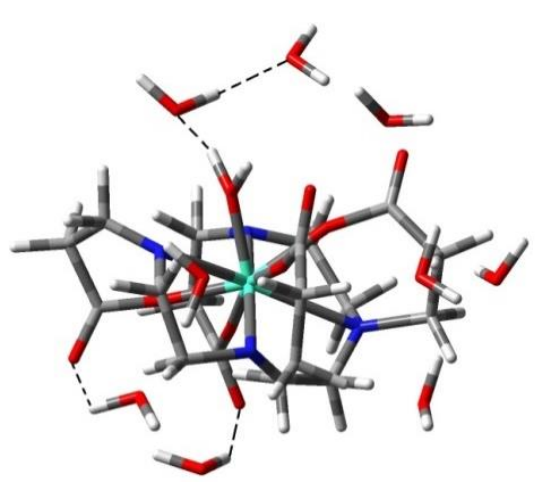

a) $\left[\mathrm{Gd}(\mathrm{DOTA})\left(\mathrm{H}_{2} \mathrm{O}\right)\right]$

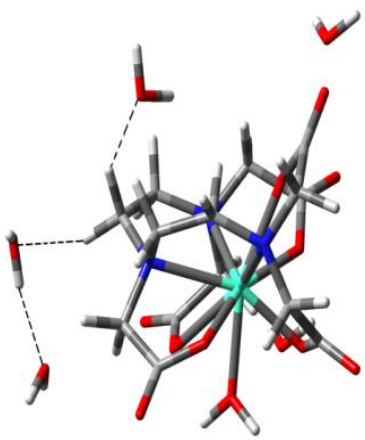

b) $\left[\mathrm{Gd}(\mathrm{DTPA})\left(\mathrm{H}_{2} \mathrm{O}\right)\right]^{2-}$

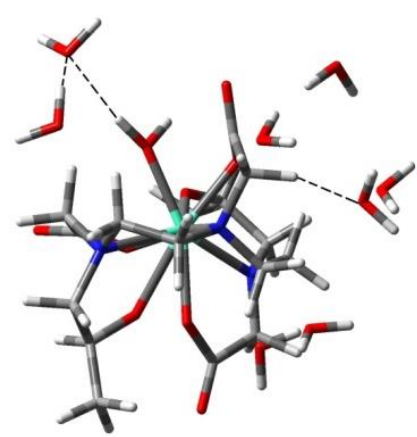

c) $\left[\mathrm{Gd}(\mathrm{DTPA}-\mathrm{BMA})\left(\mathrm{H}_{2} \mathrm{O}\right)\right]$

Figure 2. Structure of Gd(III) complexes. 
Table 1. Distance values of experimental and theoretical bond for the complex.

\begin{tabular}{|c|c|c|c|c|c|c|}
\hline \multirow[b]{2}{*}{ Bonds } & \multicolumn{2}{|c|}{$\left[\mathrm{Gd}(\mathrm{DOTA})\left(\mathrm{H}_{2} \mathrm{O}\right)\right]^{-12}$} & \multicolumn{2}{|c|}{$\left[\mathrm{Gd}(\mathrm{DPTA})\left(\mathrm{H}_{2} \mathrm{O}\right)\right]^{2-15}$} & \multicolumn{2}{|c|}{$\left[\mathrm{Gd}(\mathrm{DTPA}-\mathrm{BMA})\left(\mathrm{H}_{2} \mathrm{O}\right)\right]^{16}$} \\
\hline & Distances / § & Exp./ $\AA$ & Distances / A & Exp. / A & Distances / $\AA$ & Exp. / ̊ \\
\hline $\mathrm{Gd}-\mathrm{O}_{w}$ & 2.56 & 2.45 & 2.52 & 2.49 & 2.46 & 2.44 \\
\hline Gd-N & 2.68 & 2.65 & 2.51 & 2.64 & 2.50 & 2.67 \\
\hline $\mathrm{Gd}-\mathrm{O}_{\mathrm{c}}{ }^{1}$ & 2.10 & 2.36 & 2.45 & 2.40 & 2.30 & 2.37 \\
\hline $\mathrm{Gd}-\mathrm{O}_{\mathrm{A}}{ }^{2}$ & - & - & - & - & 2.35 & 2.44 \\
\hline
\end{tabular}

${ }^{1}$ Coordinated oxygen atoms of acetate groups.

${ }^{2}$ Oxygen atoms of amide groups.

\subsection{Time correlation}

MD calculations provide thousands of conformations, so it is possible to perform quantum calculations of all these conformations. Thus, methods to select the main structures of MD have been studied. Currently, one method that has been highly effective is statistical inefficiency ${ }^{18-21}$. With this in mind, in the present work we use statistically different structures for quantum mechanics calculations, the method uses the energy correlation function of MD simulations ${ }^{22,23}$. It is important to mention that this method was developed and studied deeply by the Coutinho and Canuto group ${ }^{23}$. The Canuto and Coutinho group showed that the statistical interval, $\mathrm{C}(\mathrm{n})$, is particularly important for a Marovian process, where $\mathrm{C}(\mathrm{n})$ follows an exponential deterioration ${ }^{22}$. In this way, uncorrelated configurations, $\tau$, is calculated by integrating zero to infinity of $\mathrm{C}(\mathrm{n})$.
Configurations separated by $2 \tau$, or larger intervals, are considered uncorrelated ${ }^{23-25}$. Figure 3 shows exponential decay.

From the simulation MD, as can be seen in Fig. 3, the correlation time of the complex coordinated with water molecules $\left(\left[\mathrm{Gd}(\mathrm{DOTA})\left(\mathrm{H}_{2} \mathrm{O}\right)\right]^{-}, \quad\left[\mathrm{Gd}(\mathrm{DTPA})\left(\mathrm{H}_{2} \mathrm{O}\right)\right]^{2-}\right.$ and [Gd(DTPA-BMA) $\left.\left(\mathrm{H}_{2} \mathrm{O}\right)\right]$ were 4.09, 6.01 and 6.53 ps, respectively. According to the calculations of statistical inefficiency for the complex $\left[\mathrm{Gd}(\mathrm{DOTA})\left(\mathrm{H}_{2} \mathrm{O}\right)\right]^{-} \quad 244 \quad$ structures were uncorrelated, for the $\left[\mathrm{Gd}(\mathrm{DTPA})\left(\mathrm{H}_{2} \mathrm{O}\right)\right]^{2-} 164$ structures were uncorrelated and for the complex [Gd(DTPA-BMA) $\left.\left(\mathrm{H}_{2} \mathrm{O}\right)\right] 153$ structures were uncorrelated. We observed that the complex [Gd(DTPA-BMA) $\left.\left(\mathrm{H}_{2} \mathrm{O}\right)\right]$ has a larger correlation time relative to other complexes, thus has a smaller number of uncorrelated structures.
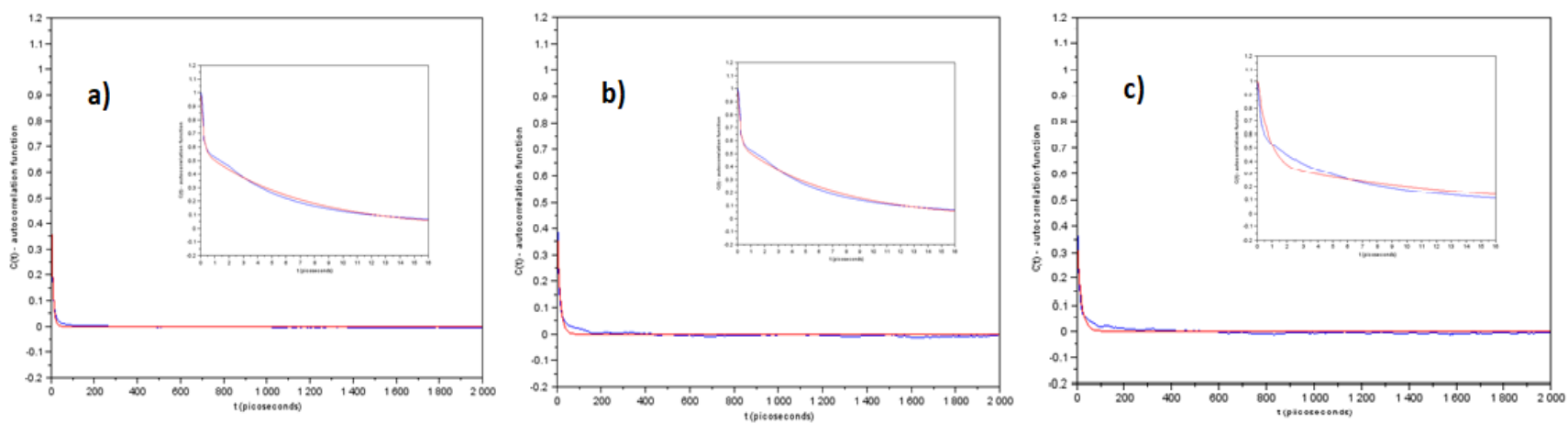

Figure 3. Graphic of the auto-correlation function for the time in picoseconds. a) $\left(\left[\mathrm{Gd}(\mathrm{DOTA})\left(\mathrm{H}_{2} \mathrm{O}\right)\right]^{-}\right.$, b) $\left[\mathrm{Gd}(\mathrm{DTPA})\left(\mathrm{H}_{2} \mathrm{O}\right)\right]^{2-}$, c) $\left[\mathrm{Gd}(\mathrm{DTPA}-\mathrm{BMA})\left(\mathrm{H}_{2} \mathrm{O}\right)\right]$. The blue curve is the correction and the red curve the adjustment done.

\subsection{Electronic and Geometric Effects on the Hyperfine Coupling Constant}

In recent decades, the MRI has emerged as a powerful diagnostic tool that uses longitudinal relaxation times $\left(\mathrm{T}_{1}\right)$ and transverse $\left(\mathrm{T}_{2}\right)$ of the atoms ${ }^{1} \mathrm{H}$ and ${ }^{17} \mathrm{O}$ of water molecules to obtain tissue images. The value $T_{1}$ is related to the return time magnetization to the longitudinal axis and it is influenced by the interaction of spins with the network (environment). The value of $\mathrm{T}_{2}$ refers to the reduction of magnetization in the transverse plane and it is influenced by the spin-spin (dipoledipole) interaction. The dipolar magnetic 
interactions between protons of water with other local interactions, are able to gradually restore the original orientation of the magnetization vector along the main magnetic field ${ }^{26}$, that way, to evaluate the influence of contrast agents on $\mathrm{T}_{1}$ and $\mathrm{T}_{2}$ times it is necessary that the compound be paramagnetic. Thus, the Eqs. 3 and 4 represent the relaxation time $T_{1}$ and $T_{2}$, respectively.

$\mathrm{R}_{1}=\frac{1}{\mathrm{~T}_{1}} \cong \frac{1}{15} \frac{\mathrm{S}(\mathrm{S}+1) \mathrm{g}^{2} \beta^{2} \mathrm{~g}^{2}{ }_{\mathrm{N}} \beta^{2} \mathrm{~N}}{\hbar^{2} \mathrm{r}^{6}}+\left(\frac{\mathrm{A}}{\hbar}\right)^{2} \frac{\mathrm{S}(\mathrm{S}+1)}{3}\left[\frac{2 \tau_{\mathrm{e}}}{1+\left(\omega_{\mathrm{I}} \tau_{\mathrm{e}}\right)^{2}}\right.$

$R_{2}=\frac{1}{T_{2}} \cong \frac{1}{15} \frac{S(S+1) g_{e}^{2} \beta^{2} g_{N}^{2} \beta_{N}^{2}}{h^{2} r^{6}}+\left(\frac{A}{\hbar}\right)^{2} \frac{S(S+1)}{3}\left[\tau_{C}+\frac{\tau_{C}}{1+\left(\omega_{S} \tau_{e}\right)^{2}}\right]$

Observing Eqs. 1 and 2, we have that the longitudinal relaxation time $\left(\mathrm{T}_{1}\right)$ depends on several parameters, such as: the electron spin (S), the electronic $\left(\mathrm{g}_{\mathrm{e}}\right)$ and proton $\mathrm{g}$ factors $\left(\mathrm{g}_{\mathrm{N}}\right)$, the Bohr magneton $(\beta)$, the nuclear magneton $\left(\beta_{N}\right)$, the hyperfine coupling constant $(A)$, the ion-nucleus distance $(r)$, and the Larmor frequencies for the proton $\left(\omega_{I}\right)$ and electron spins $\left(\omega_{S}\right), \tau_{e}$ is the correlation time that characterizes the time of internal rotational correlation of molecules. In the Eq. 2, besides the constants already mentioned we also have $\tau_{c}$, which is the correlation time characterized by the rate of change of the ion interactions between metal and neighboring hydrogens. In these equations it is important to highlight the hyperfine coupling constant, which is the most sensitive parameter and what our calculations were performed ${ }^{21}$.

We evaluate the constant values of hyperfine coupling to ${ }^{1} \mathrm{H} \mathrm{e}{ }^{17} \mathrm{O}$, and was chosen the $\mathrm{A}_{\text {iso }}$ parameters to evaluate the effects of structures, because the $A_{\text {iso }}$ values are more sensitive to geometric parameters of structures, thereby facilitating the observation of a variation of the parameters $^{27}$. Initially we will start to analyze the $A_{\text {iso }}$ coupling constant of the complex [Gd(DOTA $\left.)\left(\mathrm{H}_{2} \mathrm{O}\right)\right]^{-}$water molecules coordinated with. According to Tab. 2, we note that for the structure in equilibrium $\mathrm{A}_{i s o}^{\mathrm{eq}}\left(\mathrm{PBE} 1 \mathrm{PBE}\left(\mathrm{H}_{2} \mathrm{O}\right) / / \operatorname{PBE} 1 \mathrm{PBE}\left(\mathrm{H}_{2} \mathrm{O}\right)\right)$ obtained $\mathrm{A}_{\text {iso }}$ values equal to $0.53 \mathrm{MHz}$ for the ${ }^{1} \mathrm{H}$ and 0.87 $\mathrm{MHz}$ for the ${ }^{17} \mathrm{O}$. It was also made calculations with the implicit solvent and explicit $\mathrm{A}_{\text {iso }}^{\mathrm{eq}}(\mathrm{PBE} 1 \mathrm{PBE}$ $\left.\left(\mathrm{H}_{2} \mathrm{O}\right) / \mathrm{PCM} / / \mathrm{PBE} 1 \mathrm{PBE}\left(\mathrm{H}_{2} \mathrm{O}\right)\right)$. The values were $0.33 \mathrm{MHz}$ and $0.82 \mathrm{MHz}$ for the ${ }^{1} \mathrm{H}$ and ${ }^{17} \mathrm{O}$, respectively, the result indicate that the implicit solvent does not influence significantly our system and it shows that the amount of water molecules are allowed sufficient to realistically simulate our system. Thus, analyzing the calculations now uncorrelated with the values of $\mathrm{MD} \mathrm{A}_{\text {iso }}^{300 \mathrm{~K}}$ $\left(\mathrm{MD}\left(\mathrm{H}_{2} \mathrm{O}\right) / / \mathrm{MD}\left(\mathrm{H}_{2} \mathrm{O}\right)\right)$ we have $0.92 \mathrm{MHz}$ for the ${ }^{1} \mathrm{H}$ and $0.72 \mathrm{MHz}$ for the ${ }^{17} \mathrm{O}$. By analyzing these results, it is observed that the thermal effects influence the system, making the $\mathrm{A}_{\text {iso }}$ values closer to the experimental. This increase in $\mathrm{A}_{\text {iso }}$ values is to be expected since thermal effects are important in the system.

Table 2. Values of $A_{\text {iso }}$ of the Water in the presence of [ $\left.\mathrm{Gd}(\mathrm{DOTA})\left(\mathrm{H}_{2} \mathrm{O}\right)\right]^{-}$.

\begin{tabular}{|c|c|c|}
\hline \multicolumn{3}{|l|}{ Water in the presence of $\left[\mathrm{Gd}(\mathrm{DOTA})\left(\mathrm{H}_{2} \mathrm{O}\right)\right]^{-}$} \\
\hline & \multicolumn{2}{|c|}{$\mathbf{A}_{\text {iso }}$} \\
\hline & ${ }^{1} \mathbf{H}(\mathbf{M H z})$ & ${ }^{17} \mathrm{O}(\mathrm{MHz})$ \\
\hline $\mathrm{A}_{\text {iso }}^{\mathrm{eq}}\left(\mathrm{PBE} 1 \mathrm{PBE}\left(\mathrm{H}_{2} \mathrm{O}\right) / / \mathrm{PBE} 1 \mathrm{PBE}\left(\mathrm{H}_{2} \mathrm{O}\right)^{\mathrm{a}}\right)$ & 0.53 & 0.87 \\
\hline $\mathrm{A}_{\text {iso }}^{\mathrm{eq}}\left(\mathrm{PBE} 1 \mathrm{PBE}\left(\mathrm{H}_{2} \mathrm{O}\right) / \mathrm{PCM} / / \mathrm{PBE} 1 \mathrm{PBE}\left(\mathrm{H}_{2} \mathrm{O}\right)\right)$ & 0.33 & 0.82 \\
\hline $\mathrm{A}_{\text {iso }}^{300 \mathrm{~K}}\left(\mathrm{MD}\left(\mathrm{H}_{2} \mathrm{O}\right) / / \mathrm{MD}\left(\mathrm{H}_{2} \mathrm{O}\right)\right)$ & 0.92 & 0.72 \\
\hline Experimental & - & 0.59 \\
\hline
\end{tabular}


Analysing now the complex $\left[\mathrm{Gd}(\mathrm{DTPA})\left(\mathrm{H}_{2} \mathrm{O}\right)\right]^{2-}$, in Tab. 3, the $\mathrm{A}_{\text {iso }}$ values of equilibrium structure, $\quad \mathrm{A}_{\text {iso }}^{\mathrm{eq}}$ $\left(\mathrm{PBE} 1 \mathrm{PBE}\left(\mathrm{H}_{2} \mathrm{O}\right) / / \operatorname{PBE} 1 \mathrm{PBE}\left(\mathrm{H}_{2} \mathrm{O}\right)\right)$, was of 0.38 $\mathrm{MHz}$ for the ${ }^{1} \mathrm{H}$ and $0.85 \mathrm{MHz}$ for the ${ }^{17} \mathrm{O}$. The calculations with the implicit solvent and explicit $\mathrm{A}_{\text {iso }}^{\mathrm{eq}}\left(\mathrm{PBE} 1 \mathrm{PBE}\left(\mathrm{H}_{2} \mathrm{O}\right) / \mathrm{PCM} / / \mathrm{PBE} 1 \mathrm{PBE}\left(\mathrm{H}_{2} \mathrm{O}\right)\right)$, the values obtained were of $0.47 \mathrm{MHz}$ for the ${ }^{1} \mathrm{H}$ and $0.80 \mathrm{MHz}$ for the ${ }^{17} \mathrm{O}$, it was observed that the values of the explicit and implicit solvent next are the values only with explicit solvent, in other words, the water molecules placed as solvent were able to realistically represent our system. The calculations with uncorrelated structures of the $\mathrm{MD}, \mathrm{A}_{\text {iso }}^{300 \mathrm{~K}}\left(\mathrm{MD}\left(\mathrm{H}_{2} \mathrm{O}\right) / / \mathrm{MD}\left(\mathrm{H}_{2} \mathrm{O}\right)\right)$, we have the values of $0.65 \mathrm{MHz}$ for the ${ }^{1} \mathrm{H}$ and 0.75 for the ${ }^{17} \mathrm{O}$. Thus, the thermal effects were also shown to be important. In fact, the molecular dynamics calculations are important to simulate a more real system, thus, it is expected that the results are closer to the experimental ones.

Table 3. Values of $A_{\text {iso }}$ of the Water in the presence of $\left[\mathrm{Gd}(\mathrm{DTPA})\left(\mathrm{H}_{2} \mathrm{O}\right)\right]^{2-}$.

\begin{tabular}{|c|c|c|}
\hline & \multicolumn{2}{|c|}{$\mathbf{A}_{\text {iso }}$} \\
\hline & ${ }^{1} \mathbf{H} / \mathbf{M H z}$ & ${ }^{17} \mathrm{O} / \mathrm{MHz}$ \\
\hline $\mathrm{A}_{\text {iso }}^{\mathrm{eq}}\left(\mathrm{PBE} 1 \mathrm{PBE}\left(\mathrm{H}_{2} \mathrm{O}\right) / / \operatorname{PBE} 1 \mathrm{PBE}\left(\mathrm{H}_{2} \mathrm{O}\right)\right)$ & 0.38 & 0.85 \\
\hline $\mathrm{A}_{\text {iso }}^{\mathrm{eq}}\left(\mathrm{PBE} 1 \mathrm{PBE}\left(\mathrm{H}_{2} \mathrm{O}\right) / \mathrm{PCM} / / \mathrm{PBE} 1 \mathrm{PBE}\left(\mathrm{H}_{2} \mathrm{O}\right)\right)$ & 0.47 & 0.80 \\
\hline $\mathrm{A}_{\text {iso }}^{300 \mathrm{~K}}\left(\mathrm{MD}\left(\mathrm{H}_{2} \mathrm{O}\right) / / \mathrm{MD}\left(\mathrm{H}_{2} \mathrm{O}\right)\right)$ & 0.65 & 0.75 \\
\hline Experimental & - & 0.61 \\
\hline
\end{tabular}

Analyzing the last complex of work (Tab. 4), [Gd(DTPA-BMA $\left.)\left(\mathrm{H}_{2} \mathrm{O}\right)\right]$, the equilibrium structure, $\quad \mathrm{A}_{\text {iso }}^{\mathrm{eq}}$ $\left(\mathrm{PBE} 1 \mathrm{PBE}\left(\mathrm{H}_{2} \mathrm{O}\right) / / \mathrm{PBE} 1 \mathrm{PBE}\left(\mathrm{H}_{2} \mathrm{O}\right)\right)$, the values obtained were $0.33 \mathrm{MHz}$ for the ${ }^{1} \mathrm{H}$ and $0.89 \mathrm{MHz}$ for the ${ }^{17} \mathrm{O}$, and calculations with the implicit solvent and explicit $\mathrm{A}_{\text {iso }}^{\mathrm{eq}}$ ( $\mathrm{PBE} 1 \mathrm{PBE}\left(\mathrm{H}_{2} \mathrm{O}\right) / \mathrm{PCM} / /$ $\left.\operatorname{PBE} 1 \mathrm{PBE}\left(\mathrm{H}_{2} \mathrm{O}\right)\right)$, the values obtained were of 0.55 $\mathrm{MHz}$ for the ${ }^{1} \mathrm{H}$ and $0.75 \mathrm{MHz}$ for the ${ }^{17} \mathrm{O}$. Calculations with uncorrelated structures of the $\mathrm{MD}, \mathrm{A}_{\text {iso }}^{300 \mathrm{~K}}\left(\mathrm{MD}\left(\mathrm{H}_{2} \mathrm{O}\right) / / \mathrm{MD}\left(\mathrm{H}_{2} \mathrm{O}\right)\right)$, the values obtained were $0.95 \mathrm{MHz}$ for the ${ }^{1} \mathrm{H}$ and $0.72 \mathrm{MHZ}$ for the ${ }^{17} \mathrm{O}$. The thermal effects were important, the

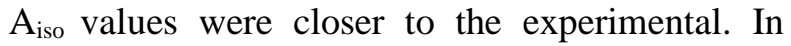

Fig. 2 are shown the structures of Gd(III) complexes with different ligands.

As noted, in both cases $\left(\left[\mathrm{Gd}(\mathrm{DOTA})\left(\mathrm{H}_{2} \mathrm{O}\right)\right]^{-}\right.$ and $\left.\left[\mathrm{Gd}(\mathrm{DTPA})\left(\mathrm{H}_{2} \mathrm{O}\right)\right]^{2-}\right)$ in both cases $\left(\left[\mathrm{Gd}(\mathrm{DOTA})\left(\mathrm{H}_{2} \mathrm{O}\right)\right]^{-}\right.$and $\left.\left[\mathrm{Gd}(\mathrm{DTPA})\left(\mathrm{H}_{2} \mathrm{O}\right)\right]^{2-}\right)$ the thermal effects were important. With the incessant movement of water molecules, more interactions can occur between the solvent and the solute and between solvent molecules (such as hydrogen bonds). These interactions are the main responsible for the considerable increase in $\mathrm{A}_{\text {iso }}$ values. The fact, thermal effects are important because they consider the movement of all solvent molecules, thus, this model is considered more realistic.

Table 4. Values of $\mathrm{A}_{\text {iso }}$ of the Water in the presence of [Gd(DTPA-BMA) $\left(\mathrm{H}_{2} \mathrm{O}\right)$ ].

\begin{tabular}{|l|c|c|}
\hline & \multicolumn{2}{|c|}{$\mathbf{A}_{\text {iso }}$} \\
\hline & \multicolumn{2}{|c|}{ Water in the presence of Gd(DTPA-BMA $\left.)\left(\mathrm{H}_{2} \mathrm{O}\right)\right]$} \\
\hline $\mathrm{A}_{\text {iso }}^{\text {eq }}\left(\mathrm{PBE} 1 \mathrm{PBE}\left(\mathrm{H}_{2} \mathrm{O}\right) / / \mathrm{PBE} 1 \mathrm{PBE}\left(\mathrm{H}_{2} \mathrm{O}\right)\right)$ & ${ }^{\mathbf{1}} \mathbf{H} / \mathbf{M H z}$ & 0.89 \\
\hline $\mathrm{A}_{\text {iso }}^{\text {eq }}\left(\mathrm{PBE} 1 \mathrm{PBE}\left(\mathrm{H}_{2} \mathrm{O}\right) / \mathrm{PCM} / / \mathrm{PBE} 1 \mathrm{PBE}\left(\mathrm{H}_{2} \mathrm{O}\right)\right)$ & 0.33 & 0.75 \\
\hline $\mathrm{A}_{\text {iso }}^{300 \mathrm{~K}}\left(\mathrm{MD}\left(\mathrm{H}_{2} \mathrm{O}\right) / / \mathrm{MD}\left(\mathrm{H}_{2} \mathrm{O}\right)\right)$ & 0.55 & 0.72 \\
\hline Experimental & 0.95 & 0.61 \\
\hline
\end{tabular}


As already mentioned, thermal effects are important. However, for our proposal of a new contrast agent this effect was neglected, in fact despite the importance of this effect, our objective is to verify if the hybrid compound can be used as CA. In this way, to reduce the computational cost, we perform calculations only with the balance structure. Thus, it was made $A_{\text {iso }}$ calculations only with the lowest energy conformer of hybrids $(\delta$ $\mathrm{FeOOH}(100) .\left[\mathrm{Gd}(\mathrm{DTPA})\left(\mathrm{H}_{2} \mathrm{O}\right)\right]^{2-}$, $\mathrm{FeOOH}(100)$. [Gd(DTPA-BMA) $\left.\left.\left(\mathrm{H}_{2} \mathrm{O}\right)\right]\right)$. The values of $\mathrm{A}_{\mathrm{iso}}$ for the hybrid compounds (Tab. 5) show that both significantly increase. For the first hybrids $\delta$ $\mathrm{FeOOH}(100)$. $\left[\mathrm{Gd}(\mathrm{DTPA})\left(\mathrm{H}_{2} \mathrm{O}\right)\right]^{2-}$ values of 4.25 $\mathrm{MHz}$ and $5.30 \mathrm{MHz}$ were obtained for the ${ }^{1} \mathrm{H} \mathrm{e}{ }^{17} \mathrm{O}$ atoms, respectively. For the hybrid $\delta$ $\mathrm{FeOOH}(100)$.[ $\left.\mathrm{Gd}(\mathrm{DTPA}-\mathrm{BMA})\left(\mathrm{H}_{2} \mathrm{O}\right)\right]$ the values of $\mathrm{A}_{\text {iso }}$ were found to be $4.15 \mathrm{MHz}$ and $5.15 \mathrm{MHz}$, respectively. Thus, it is noted that the hybrid compounds can be promising contrast agents for MRI since they showed a significant increase in the values of $\mathrm{A}_{\text {iso. }}$. Figure 4 shows the structures of hybrid compounds.

Table 5. Values of $A_{\text {iso }}$ of the water in the presence of hybrids.

\begin{tabular}{|c|c|c|}
\hline \multicolumn{3}{|c|}{ Water in the presence of $\delta-\mathrm{FeOOH}(100) \cdot\left[\mathrm{Gd}(\mathrm{DTPA})\left(\mathrm{H}_{2} \mathrm{O}\right)\right]^{-2}$} \\
\hline & \multicolumn{2}{|c|}{ A iso } \\
\hline & ${ }^{1} \mathbf{H} / \mathbf{M H z}$ & ${ }^{17} \mathrm{O} / \mathrm{MHz}$ \\
\hline$A_{\text {iso }}\left(\mathrm{PBE} 1 \mathrm{PBE}\left(\mathrm{H}_{2} \mathrm{O}\right) / / \mathrm{PBE} 1 \mathrm{PBE}\left(\mathrm{H}_{2} \mathrm{O}\right)\right)$ & 4.25 & 5.30 \\
\hline \multicolumn{3}{|c|}{ Water in the presence of $\delta$-FeOOH(100).[Gd(DTPA-BMA $\left.)\left(\mathrm{H}_{2} \mathrm{O}\right)\right]$} \\
\hline$A_{\text {iso }}\left(\mathrm{PBE} 1 \mathrm{PBE}\left(\mathrm{H}_{2} \mathrm{O}\right) / / \mathrm{PBE} 1 \mathrm{PBE}\left(\mathrm{H}_{2} \mathrm{O}\right)\right)$ & 4.15 & 5.15 \\
\hline
\end{tabular}

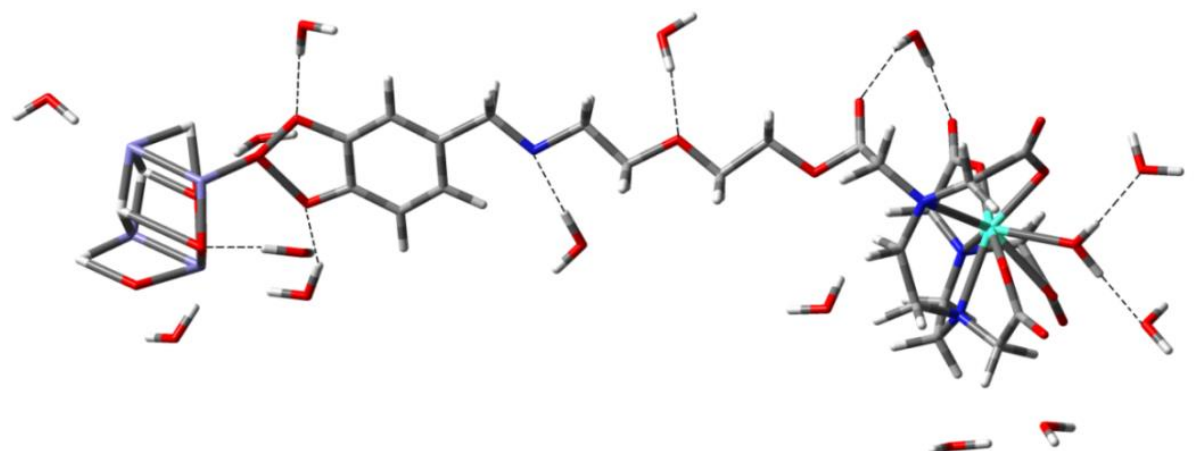

a)

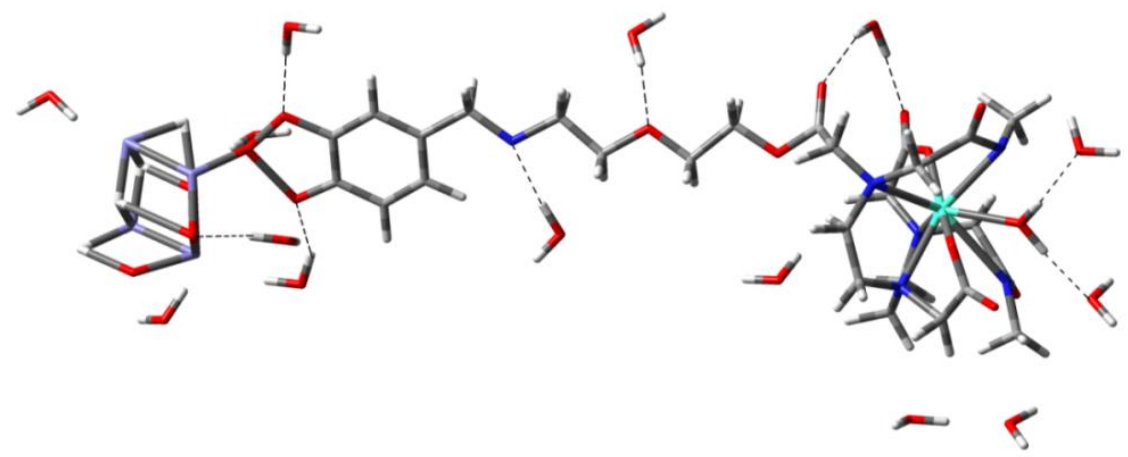

b)

Figure 4. Structures of hybrid compounds. a) $\delta$-FeOOH(100). $\left[\mathrm{Gd}(\mathrm{DTPA})\left(\mathrm{H}_{2} \mathrm{O}\right)\right]^{2-}$ b) $\delta$-FeOOH(100). $[\mathrm{Gd}(\mathrm{DTPA}-$ BMA $\left.)\left(\mathrm{H}_{2} \mathrm{O}\right)\right]$.

\section{Conclusions}

This work proposed a new hybridizing contrast agent, $\delta$-FeOOH(100). [Gd(DTPA-BMA) $\left.\left(\mathrm{H}_{2} \mathrm{O}\right)\right]$, capable of increasing both $T_{1}$ and $T_{2}$ relaxation times. The results allow to conclude that the hybrid compound may be an alternative to the classical contrast agents. 
The interaction between solvent (water) and solute (complex) significantly influences the results, that way, this is a central concern in computational chemistry simulations. Thus, the calculations suggest that the use of implicit solvent did not influence the results, showing that the solvation sphere was adequate. Therefore, the proposed hybrid compound may be a promising contrast agent for MRI.

\section{Acknowledgments}

The authors wish to thank the financial support the Conselho Nacional de Desenvolvimento Científico e Tecnológico-Brazil $(\mathrm{CNPq})$ and the Fundação de Amparo à Pesquisa do Estado de Minas Gerais - Brazil (FAPEMIG). This work was also supported by Long-term development plan UHK.

\section{References}

[1] Merbach, A. E., Helm, L., Tóth, É., The Chemistry of Contrast Agents in Medical Magnetic Resonance Imaging, 2nd ed., Wiley, New York, 2013. https://doi.org/10.1002/9781118503652.

[2] Sandra, S., Jativa, S. D., Kaittanis, C., Normand, G., Grim, J., Perez, J. M., Gadolinium-Encapsulating Iron Oxide Nanoprobe as Activatable NMR/MRI Contrast Agent, ACS Nano 6 (8) (2012) 7281-7294. https://doi.org/10.1021/nn302393e.

[3] Merbach, A. E., Tóth, É., The Chemistry of Contrast Agents in Medical Magnetic Resonance Imaging, John Wiley \& Sons, Chichester, 2001.

[4] Platas-Iglesias, C., The Solution Structure and Dynamics of MRI Probes Based on Lanthanide(III) DOTA as Investigated by DFT and NMR Spectroscopy, European Journal of Inorganic Chemistry 2012 (12) (2012) 2023-2033. https://doi.org/10.1002/ejic.201101164.

[5] Esteban-Gómez, D., de Blas, A., Rodríguez-Blas, T., Helm, L., Platas-Iglesias, C., Hyperfine Coupling Constants on Inner-Sphere Water Molecules of GdIIIBased MRI Contrast Agents, ChemPhysChem 13 (16) (2012) 3640-3650. https://doi.org/10.1002/cphc.201200417.

[6] Caravan, P., Ellinson, J. J., McMurry, T. J., Lauffer R. B., Gadolinium(III) Chelates as MRI Contrast Agents: Structure, Dynamics, and Applications,
Chemical Reviews 99 (9) (1999) 2293-2352. https://doi.org/10.1021/cr980440x.

[7] Werner, E. J., Datta, A., Jocher, C. J., Raymond, K. N., High-Relaxivity MRI Contrast Agents: Where Coordination Chemistry Meets Medical Imaging, Angewandte Chemie International Edition 47 (45) (2008) $8568-8580$

https://doi.org/10.1002/anie.200800212.

[8] Schwarz, S., Fernandes, F., Sanroman, L., Hodenius, M., Lang C., Himmelreich, U., Schmitz-Rode, T., Schueler, D., Hoehn, M., Zenke, M., Hieronymus, T., Synthetic and biogenic magnetite nanoparticles for tracking of stem cells and dendritic cells, Journal of Magnetism and Magnetic Materials 321 (10) (2009) $1533-1538$.

https://doi.org/10.1016/j.jmmm.2009.02.081.

[9] Klug, G., Kampf, T., Bloemer, S., Bremicker, J., Ziener, C. H., Heymer, A., Gbureck, U., Rommel, E., Nöth, U., Schenk, W. A., Jakob, P. M., Bauer, W. R., Intracellular and extracellular $T_{1}$ and $T_{2}$ relaxivities of magneto-optical nanoparticles at experimental high fields, Magnetic Resonance in Medicine 64 (6) (2010) 1607-1615. https://doi.org/10.1002/mrm.22557.

[10] Li Y., Yang Z., Wang B., Liu Z., Li S., Gd-complex labeled magnetite nanoparticles as fluorescent and targeted magnetic resonance imaging contrast agent, $\begin{array}{lllll}\text { Materials } & \text { Letters } & 98 & \text { (2013) } & \text { 34-37. }\end{array}$ https://doi.org/10.1016/j.matlet.2013.01.134.

[11] Davenport, A., Whiting, S., Profound Pseudohypocalcemia Due to Gadolinium (Magnevist) Contrast in a Hemodialysis Patient, American Journal of Kidney Diseases 47 (2) (2006) 350-352. https://doi.org/10.1053/j.ajkd.2005.10.024.

[12] Kartamihardja, A. A. P., Nakajima, T., Kameo, S., Koyama, H., Tsushima, Y., Impact of Impaired Renal Function on Gadolinium Retention After Administration of Gadolinium-Based Contrast Agents in a Mouse Model, Investigative Radiology 51 (10) (2016) 655-660. https://doi.org/10.1097/RLI.0000000000000295.

[13] Bloem, J. L., Wondergem, J., Gd-DTPA as a contrast agent in CT, Radiology 171 (2) (1989) 578-579. https://doi.org/10.1148/radiology.171.2.2704827.

[14] Frisch, M. J., Trucks, G. W., Schlegel, H. B., Scuseria, G. E., Robb, M. A., Cheeseman, J. R., Scalmani, G., Barone, V., Mennucci, B., Petersson, G. A., Nakatsuji, H., Caricato, M., Li, X., Hratchian, H. P., Izmaylov, A. F., Bloino, J., Zheng, G., Sonnenberg, J. L., Hada, M., Ehara, M., Toyota, K., Fukuda, R., Hasegawa, J., Ishida, M., Nakajima, T., Honda, Y., Kitao, O., Nakai, H., Vreven, T., Montgomery, J. A., 
Peralta, J. E., Ogliaro, F., Bearpark, M., Heyd, J. J., Brothers, E., Kudin, K. N., Staroverov, V. N., Kobayashi, R., Normand, J., Raghavachari, K., Rendell, A., Burant, J. C., Iyengar, S. S., Tomasi, J., Cossi, M., Rega, N., Millam, J. M., Klene, M., Knox, J. E., Cross, J. B., Bakken, V., Adamo, C., Jaramillo, J., Goperts, R., Stratmann, R. E., Yazyev, O., Austin, A. J., Cammi, R., Pomelli, C., Ochterski, J. W., Martin, R. L., Morokuma, K., Zakrzewski, V. G., Voth, G. A., Salvador, P., Dannenberg, J. J., Dapprich, S., Daniels, A. D., Farkas, O., Foresman, J. B., Ortiz, J. V., Cioslowski, J., Fox, D. J., Gaussian 09, Revision B.01. Gaussian Inc., Wallingford, 2010.

[15] Stewart, J. J. P., Optimization of parameters for semiempirical methods V: Modification of NDDO approximations and application to 70 elements, Journal of Molecular Modeling 13 (12) (2007) 1173-1213. https://doi.org/10.1007/s00894-007-0233-4.

[16] Mancini, D. T., Souza, E. F., Caetano, M. S., Ramalho, T. C., ${ }^{99}$ Tc NMR as a promising technique for structural investigation of biomolecules: theoretical studies on the solvent and thermal effects of phenylbenzothiazole complex, Magnetic Resonance in Chemistry $52 \quad$ (4) (2014) 129-137. https://doi.org/10.1002/mrc.4043.

[17] Adri van Duin, ReaxFF User Manual, 2002.

[18] Helgaker, T., Jaszuński, M., Ruud, K., Ab Initio Methods for the Calculation of NMR Shielding and Indirect Spin-Spin Coupling Constants, Chemical Reviews $\quad 99 \quad$ (1) (1999) 293-352. https://doi.org/10.1021/cr960017t.

[19] Scilab 2.7 GNU Linux, Windows 9X/NT/2000/XP, Solaris 1989-2003 INRIA/ENPC. https://www.scilab.org/.

[20] Coutinho, K., Canuto S., Solvent Effects from a Sequential Monte Carlo - Quantum Mechanical Approach, Advances in Quantum Chemistry 28 (1997) 89-105. https://doi.org/10.1016/S0065-3276(08)602099.

[21] Gonçalves, M. A., Peixoto, F. C., da Cunha, E. F. F., Ramalho, T. C., Dynamics, NMR parameters and hyperfine coupling constants of the $\mathrm{Fe}_{3} \mathrm{O}_{4}\left(\begin{array}{lll}1 & 0 & 0\end{array}\right)$-water interface: Implications for MRI probes, Chemical $\begin{array}{llll}\text { Physics } & \text { Letters } & 609 & \text { (2014) 88-92. }\end{array}$ https://doi.org/10.1016/j.cplett.2014.06.030.

[22] Goncalves, A. da S., França, T. C. C., Caetano, M. S., Ramalho, T. C., Reactivation steps by 2-PAM of tabun-inhibited human acetylcholinesterase: reducing the computational cost in hybrid QM/MM methods, Journal of Biomolecular Structure and Dynamics 32 (2)
(2014) 301-307. https://doi.org/10.1080/07391102.2013.765361.

[23] Ramalho, T. C., da Cunha, E. F. F., Alencastro, R. B., Solvent effects on ${ }^{13} \mathrm{C}$ and ${ }^{15} \mathrm{~N}$ shielding tensors of nitroimidazoles in the condensed phase: a sequential molecular dynamics/quantum mechanics study, Journal of Physics: Condensed Matter 16 (34) (2004) 61596170. https://doi.org/10.1088/0953-8984/16/34/015.

[24] Coutinho, K., Canuto, S., Zerner, M. C., A Monte Carlo-quantum mechanics study of the solvatochromic shifts of the lowest transition of benzene, The Journal of Chemical Physics $112 \quad$ (22) (2000) 9874. https://doi.org/10.1063/1.481624.

[25] Coutinho, K., Georg, H. C., Fonseca, T. L., Ludwig, V., Canuto, S., An efficient statistically converged average configuration for solvent effects, Chemical Physics Letters 437 (1-3) (2007) 148-152. https://doi.org/10.1016/j.cplett.2007.02.012.

[26] Lepage, M., Gore. J. C., Contrast mechanisms in magnetic resonance imaging, Journal of Physics: Conference Series 3 (2004) 78-86. https://doi.org/10.1088/1742-6596/3/1/008.

[27] Yazyev, O. V., Helm, L., Nuclear Spin Relaxation Parameters of MRI Contrast Agents - Insight from Quantum Mechanical Calculations, European Journal of Inorganic Chemistry $2008 \quad$ (2008) 201-211. https://doi.org/10.1002/ejic.200701013. 